\title{
Hazards posed by polycyclic aromatic hydrocarbons contained in the dusts emitted from motor vehicle braking systems
}

\author{
Zdzisław Chłopek ${ }^{1}$, Katarzyna Suchocka ${ }^{2 *}$, Magdalena Dudek ${ }^{2}$, Andrzej Jakubowski ${ }^{3}$ \\ ${ }^{1}$ Warsaw University of Technology, Poland \\ Institute of Vehicles \\ ${ }^{2}$ Automotive Industry Institute, Poland \\ Material Testing Laboratory \\ ${ }^{3}$ Automotive Industry Institute, Poland \\ ${ }^{*}$ Corresponding author's e-mail: k.suchocka@pimot.eu
}

Keywords: motor vehicles, braking systems, dusts, polycyclic aromatic hydrocarbons.

\begin{abstract}
Results of research on the hazard posed by polycyclic aromatic hydrocarbons contained in the dusts emitted from motor vehicle braking systems have been presented. The polycyclic aromatic hydrocarbons (PAHs) constitute a group of chemical compounds that pose a serious danger to the human health, chiefly because of their carcinogenic properties. Investigations into the issue of environmental pollution with polycyclic aromatic hydrocarbons generated by motor vehicle traffic were carried out in connection with the work being done at PIMOT on systems to reduce dust emission from motor vehicle braking systems. The investigations included determination of PAH contents of the dust emitted from vehicle braking systems as well as the PAH concentrations in the indoor air in a room with the stand for testing dust emissions from braking systems and in the duct to carry away gases from that room. Moreover, the PAH contents of soil were measured in the context of location of the soil sampling points in relation to traffic routes. The PAH contents were measured in Warsaw and in Zabrze. The investigation results confirmed that PAHs considered as being most harmful to the human health due to their carcinogenic properties were actually present in the dusts emitted from braking systems. The PAH contents of soil were found to be very sensitive to the location of the soil sampling points in relation to traffic routes and this is a confirmation of the thesis that motor traffic is an important source of environmental pollution with polycyclic aromatic hydrocarbons.
\end{abstract}

\section{Introduction}

The emission of dusts from motor vehicle braking systems is a serious ecological problem (Chłopek et al. 2011, Chłopek et al. 2009, Chłopek et al. 2014c, Chłopek 2012, Kieracińska et al. 2014, Report of project NR10-0050-10 2013). It is common knowledge that dusts are counted among the greatest risks to the human health (Manahan 2010), especially in urban agglomerations, where the most important dust emission sources include not only the power industry and other industrial facilities but also motor traffic (Chłopek et al. 2011, Chłopek et al. 2009, Chłopek et al. 2014c, Chłopek 2012, Kieracińska et al. 2014, Report of project NR10-0050-10 2013). Public awareness of the very serious risks posed by dusts to the human health has resulted in the fact that the regulations to protect the environment from this hazard have been significantly tightened for the recent several decades: apart from air concentration monitoring of particulate matter PM10, measurements of the level of particle matter PM2.5 in the air are also required at present (Chłopek et al. 2014b).
Among numerous automotive sources of dust emissions, e.g. exhaust systems of internal combustion engines, braking systems deserve particular attention (Chłopek et al. 2011, Chłopek et al. 2009, Chłopek et al. 2014c, Chłopek 2012, Kieracińska et al. 2014, Report of project NR10-0050-10 2013). The dust emission from the braking system of a passenger car may reach a level of even $0.5 \mathrm{~kg}$ for a one-year period (Chłopek et al. 2009). In addition to this, the dusts of this kind are extremely harmful to the human health because of very small particle size and chemical composition (Report of project NR10-0050-10 2013). A substantial majority of the dusts emitted from motor vehicle braking systems consists of particles with dimensions smaller than $1 \mu \mathrm{m}$ (Report of project NR10-0050-10 2013) (Fig. 1) and the particles of this size can penetrate to the deepest lung regions and then to the cardiovascular system.

The dusts of the PM10 fraction, especially the PM2.5 dusts, cause various respiratory diseases such as asthma or chronic bronchitis, lead to worsening of the function of lungs, and even can contribute to premature death. There is 


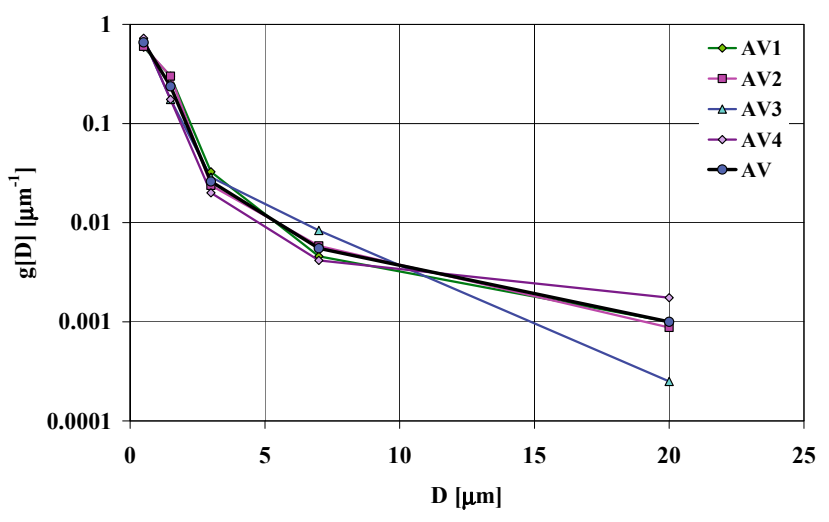

Fig. 1. Probability density of the equivalent diameter of dust particles in a sample taken from a disc brake: the average values for individual analysed places (AV1 through AV4) and the average value for the sample as a whole (AV) (Report of project NR10-0050-10 2013)

ample evidence univocally confirming that the air pollution with dusts is a factor aggravating the symptoms of chronic obstructive pulmonary disease (COPD) (MacNee 2000). Particularly harmful to the human health are the dusts that contain particles with heavy metal compounds. A material analysis of the particulate matter emitted from braking systems, carried out within the work described in publication (Chłopek et al. 2011), showed iron to be a predominating component of such dust. The presence of oxygen in the sample, revealed during that work, can be explained by the fact that the metals were contained in the particles in the form of oxides. The dust particles were also found to comprise other metals, such as barium, magnesium, aluminium, zinc, calcium, copper, silver, molybdenum, antimony, and chromium. Among non-metals, silicon and sulphur were identified as particle components.

It is a well-known fact that particles containing heavy cyclic hydrocarbons, which are carcinogenic compounds, are particularly toxic (del Rosario Sienra 2006, Hodgson 2010, Landvik et al. 2007, Manahan 2010, Nisbet et al. 1992, Smolik 2014, U.S. Department of Health and Human Services 1995). In this connection, an attempt was made in this work to explore the issue of the presence of polycyclic aromatic hydrocarbons (PAH or PAHs), also referred to as Polynuclear Aromatics (PNA or PNAs) or Polycyclic Organic Matter (POM), in environmental components contaminated by substances emitted from motor vehicle braking systems, such as ambient air. Furthermore the PAH concentration in the surface layers of soil was examined. Sampling points of soil were located at diverse distances from the automotive sources, in order to assess the impact of automotive on the contents of the above mentioned compounds in the soil.

The polycyclic aromatic hydrocarbons constitute a wide group of chemical compounds where two or more (sometimes even more than ten) aromatic rings occur in a molecule. This category includes over 200 compounds (U.S. Department of Health and Human Services, 1995), with many of them having been proven to have carcinogenic properties. PAHs have different structural forms, characterized by different arrangements of benzene rings in a molecule. In some PAH molecules, there is an area with increased free-electron density (phenanthrene structure), enabling the formation of e.g. adducts with DNA, in result of which such compounds may have an impact on the replication of a cell (Hodgson 2010, Manahan 2010, Smolik 2014, U.S. Department of Health and Human Services 1995). This may lead to mutation of genetic material and, in consequence, may be considered a factor conducive to the development of tumors.

PAHs can enter the human body through ingestion, inhalation, and dermal contact. The absorption of PAHs by the human body depends on their lipophilicity, i.e. the absorption of PAHs increases with increasing lipophilicity.

The most comprehensively tested hydrocarbon of the PAHs group is benzo(a)pyrene which, due to the strength of its carcinogenic impact and its widespread occurrence in the environment, has been recognized as a reference indicator of exposure to the whole group of polycyclic aromatic hydrocarbons. In 1992, toxic equivalency factors (TEFs), understood as relative carcinogenic potency factors determined with reference to benzo(a)pyrene, were published in (Nisbet et al. 1992) for individual PAHs. The toxic equivalency factor values for a few PAHs have been given in Table 1 .

In October 1998, a proposal was approved at a session of the Experts' Group for Chemical Factors of the Interdepartmental Commission for the List of MAC (Maximum Acceptable Concentration is the weighted average concentration of a toxic chemical compound the impact of which on an employee working for $8 \mathrm{~h}$ a day and in compliance with the average weekly working time as specified in the Labor Code over his/her working lifetime should not cause any negative changes in his/her state of health and in the state of health of his/her future descendants) and MAI (Maximum Acceptable Intensity is the maximum acceptable intensity of a physical factor harmful to the human health the impact of which on an employee working for $8 \mathrm{~h}$ a day and in compliance with the average weekly working time as specified in the Labor Code over his/her working lifetime should not cause any negative changes in his/her state of health and in the state of health of his/her future descendants). Values that an indicator, determined as a sum of products of concentrations of the nine PAHs and their TEF values (Table 1), should be introduced as a criterion for the evaluation of exposure to PAHs (Smolik 2014). This indicator has been granted the status of a requirement for PAH concentrations, effective from July 2001 on. The MAC limit thus defined for the PAH concentration is $2 \mu \mathrm{g} / \mathrm{m}^{3}$ (Smolik 2014).

PAH derivatives with nitrogen atoms incorporated in their molecular structure, referred to as NPAHs (Nitro-Polycyclic Aromatic Hydrocarbons or Nitrated Polycyclic Aromatic Hydrocarbons), have even stronger carcinogenic impact than that of ordinary polycyclic aromatic hydrocarbons. Such compounds, however, were not found in the pollutants emitted from automotive sources.

Empirical research confirms that motor traffic is a source of environmental pollution with heavy organic compounds (Chłopek et al. 2014c, Chłopek 2012, del Rosario Sienra et al. 2006, Landvik et al. 2007, Polkowska et al. 2007). The publication (Polkowska et al. 2007) presents empirically collected data on concentrations of selected pollutants in rainwater, runoff water, and river water samples taken along roads with different vehicle traffic intensities. In the water samples taken at that work, the concentrations of both organic and inorganic compounds were determined, with 
Table 1. Toxic equivalency factor (TEF) values for a few PAHs (Nisbet et al. 1992)

\begin{tabular}{|c|c|c|c|}
\hline Compound name & Molecular formula & \\
\hline Dibenzo(a,h)anthracene & $\mathrm{C}_{22} \mathrm{H}_{14}$ & \\
\hline Benzo(a)pyrene & $\mathrm{C}_{20} \mathrm{H}_{12}$ & 0.1 \\
\hline Benzo(a)anthracene & $\mathrm{C}_{18} \mathrm{H}_{12}$ & 0.1 \\
\hline Benzo(b)fluoranthene & $\mathrm{C}_{20} \mathrm{H}_{12}$ & 0.1 \\
\hline Benzo(k)fluoranthene & $\mathrm{C}_{20} \mathrm{H}_{12}$ & 0.1 \\
\hline Indeno(1,2,3-cd)pyrene & $\mathrm{C}_{22} \mathrm{H}_{12}$ & 0.01 \\
\hline Anthracene & $\mathrm{C}_{14} \mathrm{H}_{10}$ & \\
\hline Benzo(g,h,i)perylene & $\mathrm{C}_{18} \mathrm{H}_{12}$ & \\
\hline
\end{tabular}

the former including organochlorine, organonitrogen, and organophosphate pesticides, polycyclic aromatic hydrocarbons, phenols, and formaldehyde. The research results confirmed the thesis that motor transport is a significant PAH emission source.

\section{Research methods}

The hazards posed by the PAHs emitted with dusts from motor vehicle braking systems were investigated on the grounds of the following criteria:

- PAH contents of dusts and PAH concentrations in the indoor air in the environment of testing the dust emissions from braking systems;

- PAH contents of the surficial soil layer at depths ranging from 0 to $30 \mathrm{~cm}$, in the areas exposed to the impact of pollutants emitted from motor transport.

The PAH concentrations and contents in the environment of testing the dust emissions from braking systems were determined for the following locations:

- in the room with the stand for testing the dust emissions from braking systems;

- in the horizontal duct to remove gases from the room with the stand for testing the dust emissions from braking systems.
To determine the PAH contents of soil in the areas exposed to contamination by pollutants emitted from motor transport, soil samples were taken:

- at six locations situated at different distances from automotive sources in Warsaw;

- at two locations in Zabrze.

In Warsaw, three samples were taken from the ground close to an asphalt road with high traffic intensity (samples No. 1, 2, and 3); the other three samples were taken from locations situated far away from motor traffic routes. In Zabrze, the soil samples to be analysed were taken from areas adjacent to a national road.

The soil samples were examined at the Institute of Environmental Engineering of the Polish Academy of Sciences. The samples were tested according to the method PB22 "Determination of polycyclic aromatic hydrocarbons (PAH) in soil and dust by gas chromatography with mass detection" (Test Report C2-329/2013/NP-E, 2013, Test Report C2-334/2013/ NR/A Stage II, 2013, Test Report C2-334/2013/NR/A, 2013).

The dust particles produced during device operation for testing the brake pads were separated on a microfibre glass filter GF/A manufactured by Whatman, which was placed before the sorption tube (filled with resin XAD and polyurethane foam PUF). After completing the measurements both the sorption tube and the glass filters were placed in transport containers and refrigerated. The analysis of each PAHs content in dust 
and PAHs concentration in the indoor air was carried out at the Institute of Environmental Engineering of the Polish Academy of Sciences (Test Report C2-329/2013/NP-E, 2013).

The concentrations of naphthalene, acenaphthene, fluorene, anthracene, fluoranthene, phenanthrene, pyrene, benzo(a) -anthracene, chrysene, benzo(b)fluoranthene, benzo(k)-fluoranthene, benzo(a)pyrene, dibenzo(a,h)anthracene, benzo(g,h,i)perylene, indeno(1,2,3-cd)pyrene, and acenaphthylene were determined with use of the High-Performance Liquid Chromatography (HPLC) technique (Xiang et al. 2006) according to Polish Standard PN-Z-04240-5:2006.

Measurements were performed on 10.09.2013 in PIMOT and took over 5 hours and 13 minutes. The initial temperature of the room where the device was operating was $16.5^{\circ} \mathrm{C}$, while at the end of measurement temperature reached $26^{\circ} \mathrm{C}$. The measured volume of air was $8.456 \mathrm{~m}^{3}$ for the filter located in the horizontal exhaust duct of the test bench, and $6.392 \mathrm{~m}^{3}$ for the filter located in room.

\section{Research results}

The dust sampling points have been denoted as follows in the graphs:

$-\mathrm{A}$ - room of the stand for testing the dust emissions from braking systems;

- B - horizontal duct to remove gases from the stand for testing the dust emissions from braking systems.

Due to the significant differences in the levels of concentrations of individual PAHs in dust two graphs were created, as illustrated in Figures 2 and 3.

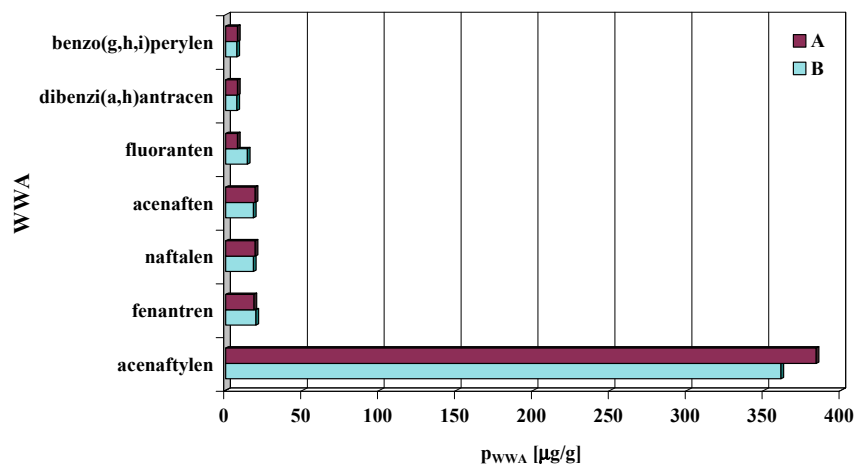

Fig. 2. PAH contents of dust samples

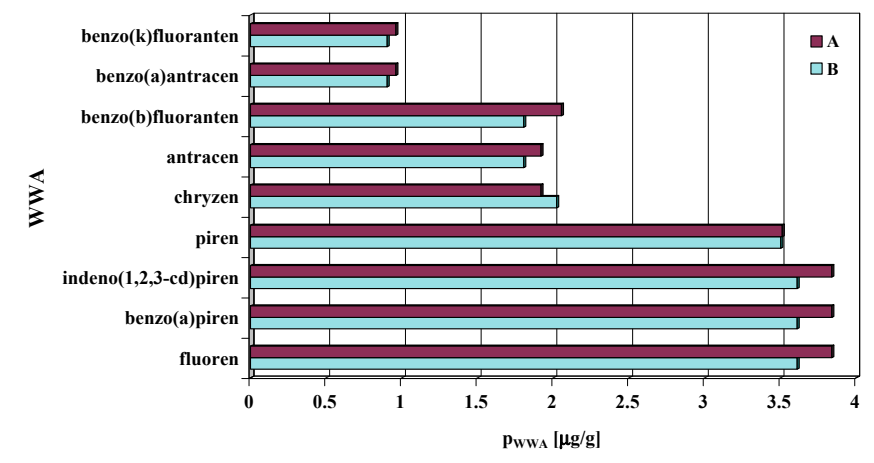

Fig. 3. PAH contents of dust samples
No big differences were revealed between corresponding PAH contents of dusts; only a trend could be observed that the PAH contents of dust samples taken from the test stand room slightly exceeded the values recorded for the samples taken from the gas removal duct, except for fluoranthene, whose concentration in the dust found in the duct was about twice as high as that in the samples taken from the test stand room. It is worth adding that the concentration of some of the compounds was adopted at the limit of quantification. In the horizontal exhaust duct of the bench, the concentration of phenanthrene, pyrene and chrysene was at or below the limit of quantification. During test concentrations of PAHs in dust in the room where the device operated, the level of phenanthrene, pyrene and benzo (b) fluoranthene was at the level of quantification.

The PAH concentrations in the indoor air have been presented in Figs. 4 and 5. Also, two graphs were created due to significant differences in the levels of concentrations of individual PAHs.

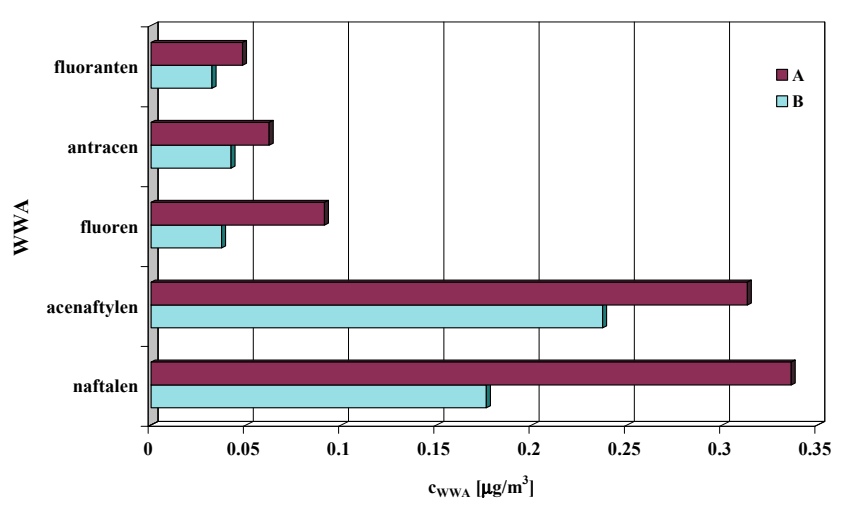

Fig. 4. PAH concentrations in the ambient air

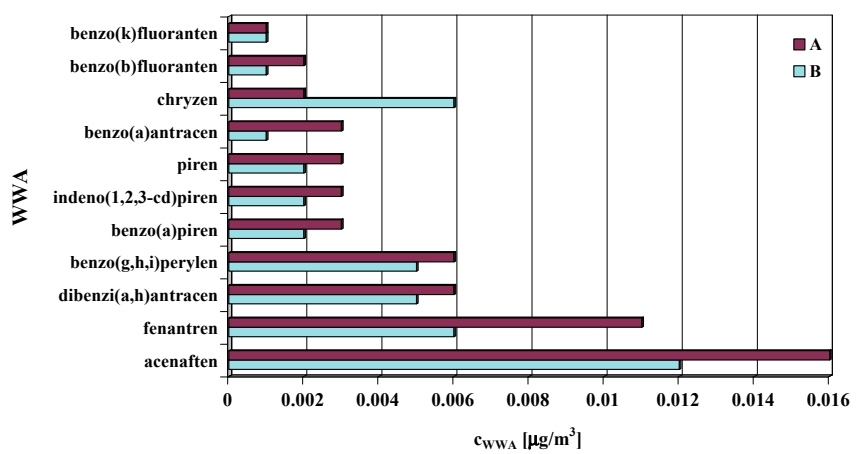

Fig. 5. PAH concentrations in the ambient air

An analysis of the empirically collected data on the concentration of polycyclic aromatic hydrocarbons in the indoor air revealed that the total $\mathrm{PAH}$ concentration in the test stand room was higher than that in the gas removal duct, which was situated at a height of about $2.5 \mathrm{~m}$. The lower concentration of particulate matter in the duct can probably be explained by the fact that air with pollutants continuously flew through the duct while the concentration of all air pollutants (both particulate matter and gaseous substances) in the room gradually rose with the test stand operation time because of the accumulation of pollutants due to the lack of air exchange. A notable exception is chrysene, according to the research work done. 
It should be emphasized that the concentrations of some of the compounds were taken at or below the limit of quantification. In a horizontal exhaust duct the concentrations of naphthalene, fluorene, phenanthrene, anthracene, fluoranthene, pyrene, chrysene were at or below the limit of quantification, whereas for the indoors operation of the device, the concentrations of naphthalene, fluorene, phenanthrene, anthracene, fluoranthene, pyrene, Bezno (a) anthracene were also at or below the limit of quantification.

The PAH concentration in the indoor air and the PAH contents of dusts are weakly correlated with each other (Fig. 6) in spite of low values of the probability that the hypothesis of absence of the correlation will not be rejected. For the data collected from the room, the Pearson linear correlation coefficient value is 0.658 and the probability that the hypothesis of the absence of the Pearson's linear correlation will not be rejected is below 0.01; for the data collected from the duct, the corresponding coefficient and probability values are 0.798 and below 0.01 , respectively.

The PAH contents of soil were determined for six locations situated at different distances from automotive sources in

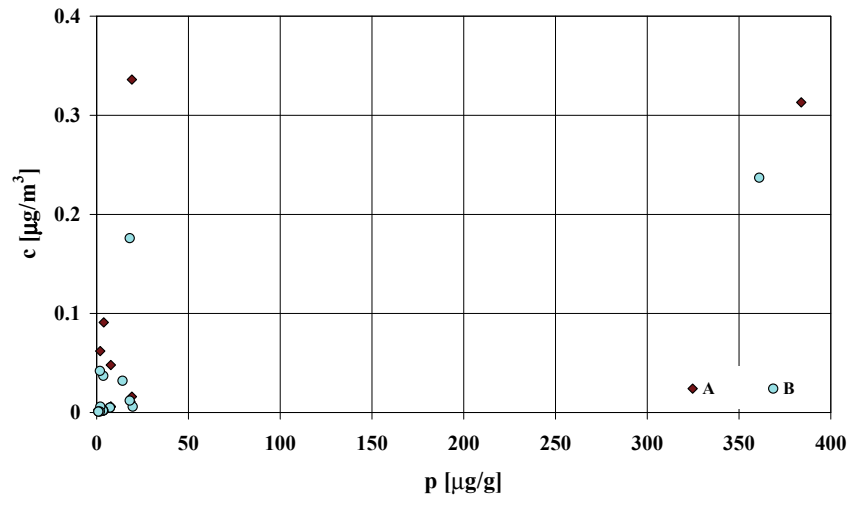

Fig. 6. Correlation interdependence between the total PAH concentration in the ambient air and the total PAH content of the dusts
Warsaw and for two locations in Zabrze. The soil sampling depth was $5 \mathrm{~cm}$ in Warsaw and about $30 \mathrm{~cm}$ in Zabrze. In Warsaw, three samples were taken close to an asphalt road with high traffic intensity (sampling point W1 at Starzyński roundabout towards Jagiellońska Street, sampling point W2 at Starzyński roundabout towards Haller's Square, and sampling point W3 at Starzyński roundebout towards the bridge) and three other samples were taken on the premises of the Automotive Industry Institute (PIMOT), i.e. one at the former filling station (sampling point W4), one in a grass area named "meadow" (sampling point W5), and one in a parking area with a hardened but not asphalted surface (sampling point W6). In Zabrze, the soil samples were taken at locations situated at national road No. 88, built in the 1930s, connecting the towns of Bytom and Strzelce Opolskie. The road has an asphalt surface and is characterized by high motor traffic density. The test samples were taken from a road shoulder, about $1 \mathrm{~m}$ away from the asphalt roadway. The sample taken close to Franciszkańska Street was examined for the presence of $\mathrm{PAH}$ at two depths, i.e. 5-20 $\mathrm{cm}$ (sampling point Z1) and $20-30 \mathrm{~cm}$ (sampling point $\mathrm{Z2}$ ), and the one taken close to a car park was examined at three depths, i.e. 0-5 cm (sampling point Z3), 5-20 cm (sampling point Z4) and 20-30 cm (sampling point Z5).

The test results of the PAHs contents in the soil in the measuring positions are determined by all sources of emissions of PAH associated with areas which include the measuring positions. For measuring positions selected in areas with high traffic intensity of motor vehicles, the emission sources of PAHs are not only the dust from brake system, but also from the exhaust gases from engines. Due to the fact that the objects of the research are heavy hydrocarbons, these sources are primarily compressionignition engines, powered by heavy fuel. Also, engine oil consumption, both for compression-ignition engines and spark-ignition engines, is the reason for the emission of heavy hydrocarbons, including PAHs.

The PAH contents of soil at the sampling points in Warsaw have been presented in Fig. 7.

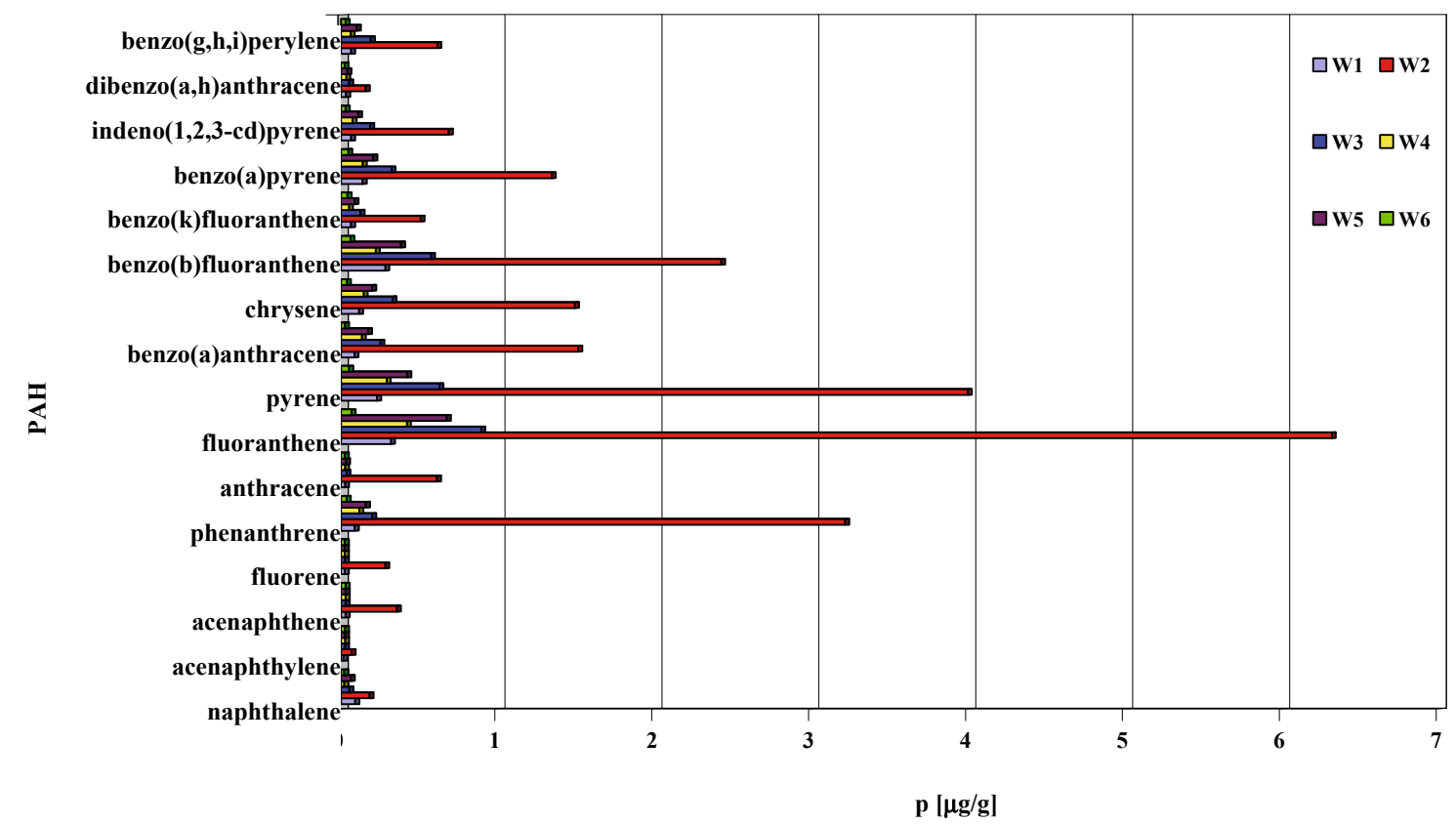

Fig. 7. PAH contents of soil at the sampling points in Warsaw 
The most contaminated soil sample was the one taken at the W2 sampling point at Starzyński roundebout towards Haller's Square. The sampling point was situated most closely to the roadway. The other sampling points at Starzyński roundebout were situated a little bit farther from the roadway edge, close to the tram line. Besides, traffic congestions are often formed in the vicinity of Starzyński roundebout, which may be considered a reason for the high PAH content of soil in that area. Among all the PAHs tested for the W2 sampling point, the highest and lowest PAH content values were recorded for fluoranthene and acenaphthylene, respectively. In Warsaw, the lowest individual PAH content values were recorded for the sampling point situated in the parking area at PIMOT (W6). The fact that the lowest PAH contents were recorded in the parking area instead of the "meadow" was most likely caused by the site repair works carried out quite recently, during which fresh earth was probably brought there. If the samples had been taken from deeper levels, maybe higher PAH content values would have been recorded. After analysis of the data obtained, a conclusion was additionally formulated that in every case individual PAH contents should also have been determined for different sampling depths because polycyclic aromatic hydrocarbons, like heavy metals, are washed out and penetrate into deeper soil layers. Obviously, such a washout process depends on the soil type, chiefly on the soil permeability. This difference is particularly conspicuous for such compounds as fluoranthene, pyrene, phenanthrene, benzo(b)fluoranthene, benzo(a)anthracene, chrysene, and benzo(a)pyrene. The fluoranthene content of the sample taken at Starzyński roundebout towards Haller's Square (i.e. at the W2 sampling point) was about 9 times as high as that recorded for the parking area at PIMOT (W6). The lowest PAH content values were recorded for acenaphthylene at Starzyński Square towards Haller's Square (W2) and for naphthalene in the parking area at PIMOT (W6).
It is worth noting that the concentrations of PAHs listed below were at or below the limit of quantification:

- acenaphthene, fluorene and anthracene in the soil sample obtained at point $\mathrm{W} 1$,

- acenaphthylene, acenaphthene and fluorene in thesoil sample obtained at th point W3,

- naphthalene, acenaphthylene, acenaphthene and fluorene in thesoil sample obtained at point W4,

- acenaphthylene, acenaphthene and fluorene in the soil sample obtained at point W5,

- each of the detected at point W6.

The PAH contents of soil samples taken in Zabrze have been presented in Fig. 8.

The PAH content of soil in Zabrze is lower than that in Warsaw. For almost all the PAHs under consideration, the highest contents were recorded at Z2 sampling point (at a depth of 20-30 cm); the lowest contents occurred at Z3 location (at a depth of $0-5 \mathrm{~cm})$. The data collected in Zabrze indicate that the PAH content of soil rises with increasing depth. The biggest differences in the PAH contents were found for benzo(b) fluoranthene, benzo(a)pyrene, and indeno(1,2,3-cd)pyrene. The benzo(b)fluoranthene content at a depth of $20-30 \mathrm{~cm}$ (Z2) was almost 7 times as high as that recorded at a depth of $0-5 \mathrm{~cm}(Z 3)$. Based on the soil examination results and on a comparison between them and the requirements laid down for soils in the Regulation of the Minister of the Environment of 9 September 2002 on the soil and earth quality standards, a finding may be formulated that the soils under examination met the said requirements. According to the Regulation mentioned above, soils are divided into three groups:

- group A, i.e. areas protected on the grounds of regulations of the Act "Law on Use and Conservation of Inland Waters" and areas protected on the grounds of nature conservation regulations;

- group B, i.e. arable land, forest grounds, wooded and shrub bed areas, wasteland, as well as built-up and

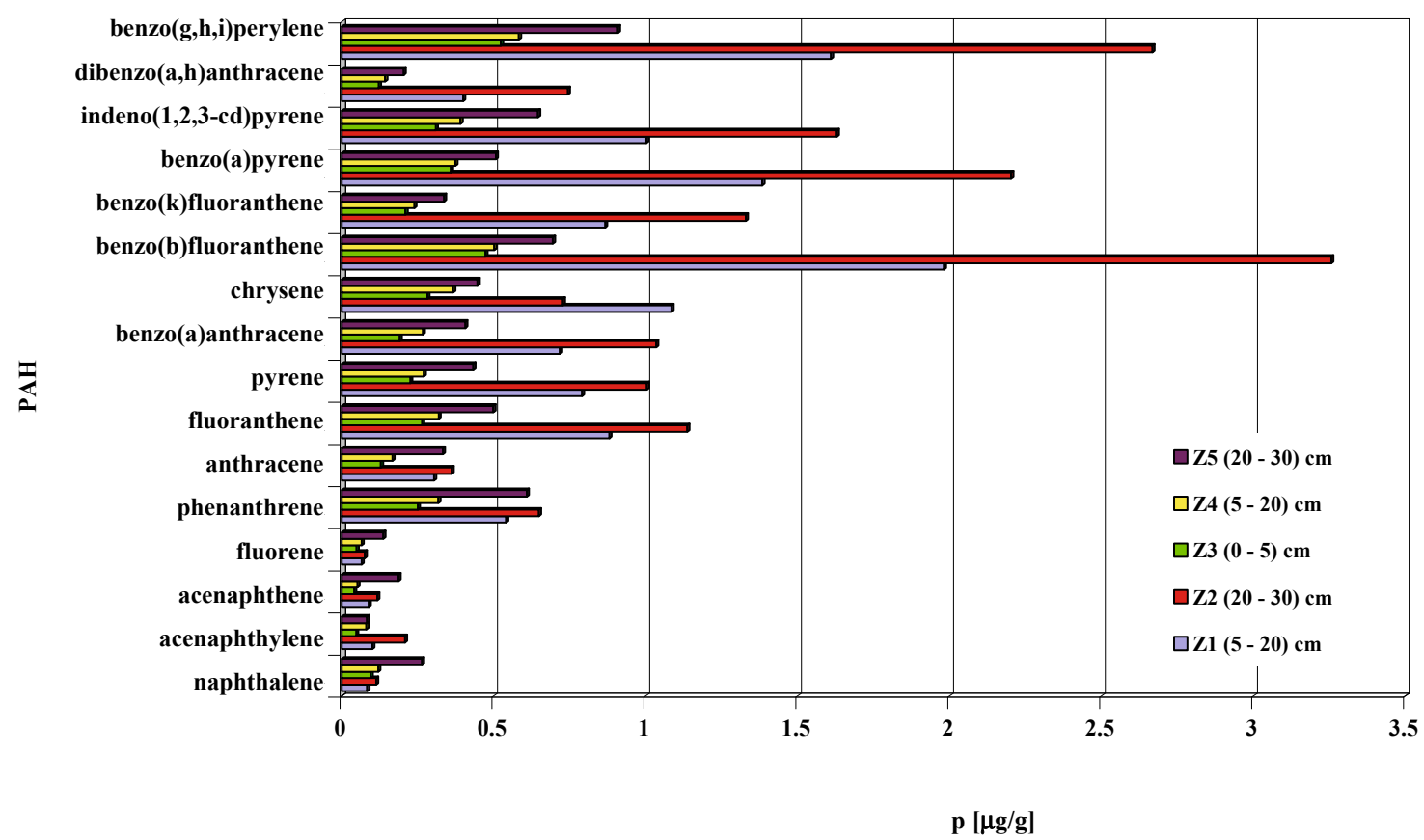

Fig. 8. PAH contents of soil at the sampling points in Zabrze 
urbanized grounds, excluding industrial, mining, and traffic areas;

- group C, i.e. industrial, mining, and traffic areas.

The sampling points were situated within traffic and industrial areas; therefore, the PAH contents recorded met the applicable regulations.

\section{Recapitulation}

Dusts pose a serious danger to the human health, especially in central parts of large urban agglomerations, where many people are exposed and the environmental pollution comes from numerous intensively operating sources related to civilization. In urban agglomerations, a significant part of dust emissions comes from motor traffic. The dusts emitted from braking systems are extremely dangerous due to very small particle size, often below $1 \mu \mathrm{m}$, and their chemical composition, as the dusts contain heavy metals and heavy hydrocarbons.

Results of empirical examinations of dusts emitted from braking systems have confirmed the fact that particles of such dusts contain polycyclic aromatic hydrocarbons, which have been proven to be conducive to the occurrence and development of tumors. The chemical compounds identified at the research works and found to be present in the dusts emitted from braking systems are counted among the group of most potent carcinogenic PAHs. The research on the PAH contents of soil has shown that motor traffic is an important source of such compounds. Although hydrocarbons come from many different sources related to motor vehicle traffic, the research work results described previously have provided evidence that the processes connected to wear of tribological elements in braking systems are among the reasons for PAH emissions.

The harmful impact of polycyclic aromatic hydrocarbons on the human health is so strong that the searching for any solutions that would help to reduce the emissions of such compounds is counted among the specially prioritized actions taken to reduce hazards to the human health. As an effect of such actions, systems to reduce the particulate matter emission from motor vehicle brake mechanisms have been developed at the Automotive Industry Institute (PIMOT) (Chłopek et al. 2014a, Chłopek et al. 2011, Chłopek et al. 2009).

This paper presents the outputs of the project No. CDS084-BZS/M.13B "Development of methods to examine polycyclic aromatic hydrocarbons generated during the operation of motor vehicles", implemented at the Automotive Industry Institute in 2013 within Institute's statutory activities.

\section{References}

Chłopek, Z., Jakubowski, A., Kieracińska, A. \& Lasocki, J. (2014a). Prototypes of devices to reduce dust emissions from vehicles braking systems, Proceedings of the Institute of Vehicles, 1(97), pp. 41-49. (in Polish)

Chłopek, Z., Jakubowski, A. \& Kieracińska, A. (2011). Examination of a laboratory system to reduce dust emission from braking systems of automotive vehicles, The Archives of Automotive Engineering - Archiwum Motoryzacji, 3, 5-17, pp. 103-115.

Chłopek, Z. \& Jakubowski, A. (2009). A study of the particulate matter emission from the braking systems of motor vehicles, Eksploatacja i Niezawodność - Maintenance and Reliability, 4(4), pp. 45-52.

Chłopek, Z. \& Suchocka, K. (2014b). The analysis of environmental protection regulations prior to particulate matter emissions in terms of traffic, Proceedings of the Institute of Vehicles, 1(97), pp. 21-32. (in Polish)

Chłopek, Z. \& Suchocka, K. (2014c). Risk posed by particulate matter to the human health and environment near transport routes, The Archives of Automotive Engineering - Archiwum Motoryzacji, 63, 1, 3-22, pp. 109-129.

Chłopek, Z. (2012). Testing of hazards to the environment caused by particulate matter during use of vehicles, Eksploatacja i Niezawodność - Maintenance and Reliability, 2, pp. 160-170.

del Rosario Sienra, M. \& Rosazza, N.G. (2006). Occurrence of nitro-polycyclic aromatic hydrocarbons in urban particulate matter PM10, Atmospheric Research, 81, 4, pp. 265-276.

Hodgson, E. (2010). A Textbook of Modern Toxicology, John Wiley and Sons, 2010.

Kieracińska, A. Biedrzycki, J., Chłopek, J., Jakubowski, A., Lasocki, J. \& Wójcik, P. (2014). Examining of the effectiveness of operation of a system to reduce particulate matter emission from motor vehicle brake mechanisms in conditions simulating the real vehicle use, The Archives of Automotive Engineering - Archiwum Motoryzacji, 63, 1, 35-50, pp. 141-156.

Landvik, N.E., Gorria, M., Arlt, V.M., Asare, N., Solhaug, A., Lagadic-Gossmann, D. \& Holme, J.A. (2007). Effects of nitrated-polycyclic aromatic hydrocarbons and diesel exhaust particle extracts on cell signalling related to apoptosis: Possible implications for their mutagenic and carcinogenic effects, Toxicology, 2, pp. 159-174.

Borowski, G. (ed.) (2010). Ecoengineering lexicon, PTIE - Polish Society of Ecological Engineering, Warszawa 2010. (in Polish)

MacNee, W. \& Donaldson, K. (2000), Exacerbations of COPD - environmental mechanism, Chest Journal, 117, pp. 390-397.

Manahan, S.E. (2010). Environmental Toxicology. Aspects of chemical and biochemical, PWN, Warszawa 2010. (in Polish)

Nisbet, I.C. \& LaGoy, P.K. (1992). Toxic equivalency factors (TEFs) for polycyclic aromatic hydrocarbons (PAHs), Regulatory Toxicology and Pharmacology Journal, Elsevier, 1992, 16(3), pp. 290-300.

Polkowska, Ż. Dubiella-Jackowska, A., Zabiegała, B. \& Namieśnik, J. (2007). Composition of pollutants in the water samples collected along the highways with different traffic intensity, Ecological Chemistry and Engineering, 14, 3. (in Polish)

Smolik, E. Polycyclic aromatic hydrocarbons (http://www.ietu. katowice.pl/wpr/Dokumenty/Materialy_szkoleniowe/Szkol2/10smolik.pdf (20.04.2014)). (in Polish)

Test report C2-329/2013/NP-E: Measuring the PAH concentrations in the gas removed from a brake pad testing stand at PIMOT in Warsaw. Polish Academy of Sciences, Institute of Environmental Engineering, Zabrze 2013. (in Polish, not published)

Test report C2-334/2013/NR/A Stage II: Examining five soil samples for the presence of PAH. Polish Academy of Sciences, Institute of Environmental Engineering, Zabrze 2013. (in Polish, not published).

Test report C2-334/2013/NR/A: Examining six soil samples for the presence of PAH. Polish Academy of Sciences, Institute of Environmental Engineering, Zabrze 2013. (in Polish, not published).

Report of project NR10-0050-10: Development of systems to reduce dust emission from disc brake and drum brake mechanisms of motor vehicles. Automotive Industry Institute, Warszawa 2013. (in Polish, not published).

Toxicological profile for polycyclic aromatic hydrocarbons. U.S. Department of Health and Human Services. Public Health Service Agency for Toxic Substances and Disease Registry, August 1995.

Xiang, Y., Liu, Y. \& Lee, M.L. (2006). Ultrahigh pressure liquid chromatography using elevated temperature, Journal of Chromatography A, 1104 (1-2), pp. 198-202. 


\section{Zagrożenia wielopierścieniowymi węglowodorami aromatycznymi z pyłów z samochodowych układów hamulcowych}

Streszczenie: W artykule przedstawiono wyniki badań zagrożenia wielopierścieniowymi węglowodorami pierścieniowymi z pyłów z samochodowych układów hamulcowych. Wielopierścieniowe węglowodory aromatyczne (WWA) stanowią grupę związków, będących poważnym zagrożeniem dla zdrowia ludzi, głównie z powodu swych właściwości kancerogennych. W związku z pracami prowadzonymi w Przemysłowym Instytucie Motoryzacji nad urządzeniami do zmniejszania emisji cząstek stałych z samochodowych układów hamulcowych przeprowadzono badania dotyczące motoryzacyjnych zanieczyszczeń środowiska wielopierścieniowymi węglowodorami aromatycznymi. Badano zawartość WWA w pyłach pochodzących z układów hamulcowych oraz stężenie WWA w powietrzu w pomieszczeniu ze stanowiskiem do badań par trybologicznych układów hamulcowych, a także w kanale odprowadzającym gazy z tego pomieszczenia. Badano również zawartość WWA w glebie w różnych miejscach ze względu na usytuowanie w stosunku do tras komunikacyjnych. Badania zawartości WWA wykonywano w Warszawie i Zabrzu. W wyniku przeprowadzonych badań stwierdzono, że pyły hamulcowe zawierają WWA z grupy związków najbardziej szkodliwych ze względu na właściwości kancerogenne. Stwierdzono znaczną wrażliwość zawartości WWA w glebie na położenie względem tras komunikacyjnych, co potwierdza fakt, że motoryzacja jest znaczącym źródłem zanieczyszczenia środowiska wielopierścieniowymi węglowodorami aromatycznymi. 